\title{
Diagnosis and management of hereditary colorectal cancer syndromes: Lynch syndrome as a model
}

\author{
Henry T. Lynch MD, Jane F. Lynch BSN, Thomas A. Attard MD
}

Previously published at www.cmaj.ca on Aug. 3, 2009.

$\mathrm{T}$ his article deals exclusively with the hereditary forms of colorectal cancer. Clinical examples of hereditary colorectal cancer syndromes abound; of these, familial adenomatous polyposis and Lynch syndrome are the most common and well known (Figure 1). ${ }^{1}$ In this review, we use Lynch syndrome as an example for the diagnosis, testing of germ cells for mutations, surveillance and management of hereditary colorectal cancer.

Lynch syndrome is the most common hereditary syndrome that predisposes patients to colorectal cancer. It accounts for $2 \%-5 \%$ of the total burden of colorectal cancer. ${ }^{2}$ The estimated number of new colorectal cancer cases in Canada in 2008 was $21500 .^{3}$ Thus, Lynch syndrome accounted for as many as 1075 cases in Canada in 2008. Each patient with Lynch syndrome may represent a family in which multiple family members can be expected to develop colorectal cancer or an integral extracolonic cancer. Clearly, these families have an important impact on public health policy.

The second most common hereditary colorectal cancer syndrome is familial adenomatous polyposis, which is responsible for less than $1 \%$ of all colorectal cancer cases. ${ }^{4}$ Other identified syndromes that predispose patients to colorectal cancer are even less common (Figure 1). However, we still have much to learn about the basis of "familial" colorectal cancer.

In 1966, our team described 2 large families from the midwestern United States with an apparent excess number of members with colorectal cancer that lacked multiple colonic adenomas. ${ }^{5}$ This disorder involved a variety of extracolonic cancer sites and was therefore initially referred to as the "cancer family syndrome." It was subsequently renamed hereditary nonpolyposis colorectal cancer syndrome. Since the identification of mismatch repair mutations in this syndrome, it has become known as Lynch syndrome ${ }^{6,7}$ (Online Mendelian Inheritance in Man database no. 120435). ${ }^{8}$ The name hereditary nonpolyposis colorectal cancer syndrome is given to disorders that have similar phenotypes but that lack the specific mutations involved in + Lynch syndrome (e.g., familial colorectal cancer type X). ${ }^{9,10}$

Advances in molecular diagnostics in the last 15 years have changed the landscape of Lynch syndrome. It is now quite common to identify a germline mutation in one of the mismatch repair genes. The most common mutations are those in $\mathrm{MLH1}$ and $\mathrm{MSH} 2{ }^{4}$ Microsatellite instability testing and immunohistochemistry are useful tools to determine

\section{Key points}

- A number of hereditary syndromes may predispose patients to colorectal cancer.

- The most common is Lynch syndrome, followed by familial adenomatous polyposis.

- The primary care physician has a vital role in recognizing the possibility of a hereditary syndrome that predisposes patients to colorectal cancer.

- Targeted surveillance and management based on the syndrome's natural history may reduce mortality.

whether a patient is a candidate for testing for mutations in the mismatch repair genes. ${ }^{4,11}$

Advances in molecular genetics, particularly in the identification of cancer-causing mutations in germ cells, have made it possible to establish whether patients are at high risk of hereditary cancers. In this review, we discuss some of the distinguishing features of hereditary colorectal cancer syndromes and outline the role that primary care physicians play in the detection of hereditary colorectal cancer syndromes and the care of affected patients.

\section{A recently identified mutation: $M Y H$}

The $M Y H$ gene plays an active role in protecting genomic integrity during transcription. Although most hereditary cancer syndromes have an autosomal dominant inheritance pattern, $M Y H$ mutations are autosomal recessive, which means that a mutation must occur in both alleles of the gene in order for disease to develop. The effect of a monoallelic mutation in $M Y H$ is unclear. There is phenotypic overlap between milder, attenuated forms of familial adenomatous polyposis and $M Y H$-associated polyposis. However, $M Y H$-associated polyposis typically results in a different pattern of extracolonic cancers, including breast cancer ${ }^{12}$ sebaceous adenocarcinoma and endometrial cancer. ${ }^{13}$ The possibility of sebaceous adeno-

Henry Lynch, Jane Lynch and Thomas Attard are with the Department of Preventive Medicine and Public Health, Creighton University School of Medicine, Omaha, USA.

Cite as CMAJ 2009. DOI:10.1503/cmaj.071574 
carcinoma in this syndrome overlaps with Muir-Torre syndrome, which is a variant of Lynch syndrome. ${ }^{14,15}$

Expanded testing, screening and management criteria are being developed for $M Y H$-associated polyposis. $M Y H$ mutation testing is indicated for patients with multiple colonic adenomas who do not have an APC mutation. Based on their study that included 453 patients with multiple colorectal adenomata and no APC mutation, Olschwang and coworkers ${ }^{16}$ suggested an early screening program, beginning between ages 25 and 30, that includes endoscopy of the upper digestive tract and colorectum every 2 years.

As with any hereditary colorectal cancer syndrome, screening and management recommendations are based on the natural history of the disorder along with the results of genetic testing (Table 1, Table 2).

\section{Family history}

A family history that includes most, if not all, relevant details can be collected at the time of patient intake or registration by use of a structured questionnaire that can be reviewed and addressed during the clinic visit. An alternative to a printed questionnaire is the online tool for recording family medical history provided by the United States Department of Health and Human Services (www.hhs.gov/familyhistory/) as part of the
United States Surgeon General's Family History Initiative. The suspicion of a hereditary cancer syndrome often results from recognition of a familial pattern of disease, such as a constellation of early colorectal, genitourinary, breast and selected types of other cancers. ${ }^{20}$ Ideally, the patient's family history will include information about cancers of all anatomic sites, with approximate ages of onset, for the patient's first-degree relatives (parents, siblings, children) and, whenever possible, seconddegree relatives (maternal and paternal aunts, uncles and grandparents). Figure 2 shows the family members who should, whenever possible, be included in this modified nuclear pedigree. Older family members will have often passed the cancer risk age and, therefore, will be more genetically informative.

\section{Referral to a geneticist or cancer centre}

Referral to a medical geneticist or a hereditary cancer centre can be made at any time during the family workup process, depending on the complexity of the clinical or genetic problem, the physician's individual expertise and the resources available. The rates of referral for DNA testing for cancercausing mutations are low throughout the world, even among patients with a family history of cancer. For example, Murff and colleagues ${ }^{22}$ reported that, of 6 candidates at high risk for breast cancer, only 1 was referred for $B R C A$ testing.

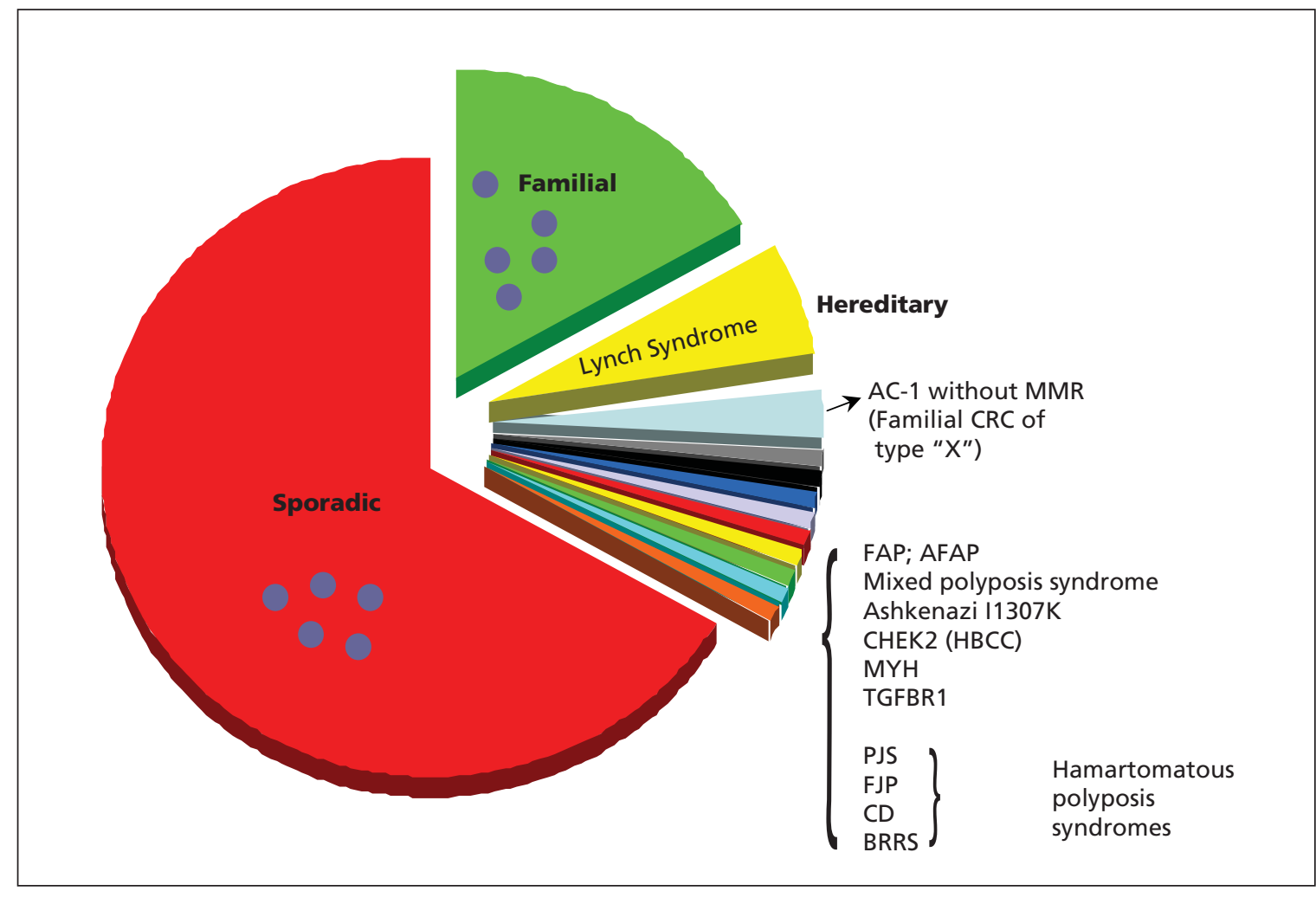

Figure 1: Circle graph depicting the marked genotypic and phenotypic heterogeneity in hereditary colorectal cancer syndromes. Circles indicate as yet undiscovered variants of heriditary cancers. Note: AC-1 = Amsterdam Criteria $\mathrm{I}, \mathrm{MMR}=$ mismatch repair, $\mathrm{FAP}=$ familial adenomatous polyposis, $\mathrm{AFAP}=$ attenuated familial adenomatous polyposis, HBCC = hereditary breast and colorectal cancer, PJS = Peutz-Jeghers syndrome, FJP = familial juvenile polyposis, $C D=$ Cowden disease, BRRS = Bannayan-Ruvalcaba-Riley syndrome. Modified with permission from The American Cancer Society, Inc. ${ }^{1}$ 
Guttmacher and colleagues ${ }^{23}$ reported that only $17 \%$ of patients who would be considered as candidates for genetic testing were referred for testing. It is unfortunate that so many patients are not receiving the many benefits of molecular genetic testing. Knowledgeable primary care physicians are key to improving these numbers.

\section{Comprehensive family pedigree}

If a hereditary cancer syndrome is suspected, a comprehensive family history for cancer can supplement a patientreported family history. Patient-reported family histories for cancer are accurate and valuable for assessing the risk of breast cancer and colorectal cancer but are less accurate for more rare types of cancer. ${ }^{24}$ Primary care physicians may wish to construct the more detailed comprehensive family history, but this is more commonly done by a genetic counsellor or a medical geneticist after referal.

The comprehensive family pedigree incorporates all of the available cancer findings in the family, including cancer of all anatomic sites with age of onset ${ }^{25}$ and pathology documentation (if available) as well as pertinent noncancer phenotypic features, such as perioral pigmentation in Peutz-Jeghers syndrome, multiple colonic adenomas in familial adenomatous polyposis, a paucity of polyps in its attenuated familial adenomatous polyposis counterpart, and the presence of sebaceous adenomas, sebaceous carcinomas and multiple keratoacanthomas in MuirTorre syndrome (a variant of Lynch syndrome)., ${ }^{426}$ Table 1 shows the characteristics of hereditary polyposis syndromes, and those of Lynch syndrome are listed in Box 1.

\section{Genetic testing}

It is essential to determine which patients need to be tested for hereditary cancer syndromes. ${ }^{27} \mathrm{We}$ recommend that the following criteria be met before a patient is referred to a medical geneticist or a hereditary cancer centre or before genetic testing: a family history consistent with the hereditary cancer syndrome of concern; a mutation for which testing exists that has been identified as causal to the syndrome; availability of comprehensive genetic counseling, ${ }^{28}$ with risks and benefits understood to have truly informed patient consent; and the existence of useful surveillance or management options, or both, for carriers of the mutation that would affect the patient's care.

The most genetically informative family member is one with an early-onset syndrome cancer who is in the patient's direct line of hereditary descent (e.g., a parent, sibling or child affected by a syndrome cancer). This family member would be the most likely family member to carry the family's deleterious mutation, if there is one present in the family. If a mutation is identified in a likely carrier, it is possible for other family members to undergo "mutation-specific testing," which has lesser cost and higher accuracy than the initial testing needed to identify the specific mutation.

Once a family's cancer-causing mutation has been identified, it is necessary to decide which other family members

Table 1: Characteristics of hereditary polyposis syndromes

\begin{tabular}{|c|c|c|c|c|c|}
\hline Characteristic & $\begin{array}{c}\text { Familial adenomatous } \\
\text { polyposis }\end{array}$ & $\begin{array}{l}\text { Attenuated familial } \\
\text { adenomatous } \\
\text { polyposis }\end{array}$ & $\begin{array}{c}M Y H \text {-associated } \\
\text { polyposis }\end{array}$ & $\begin{array}{l}\text { Juvenile } \\
\text { polyposis }\end{array}$ & Peutz-Jeghers \\
\hline $\begin{array}{l}\text { Adenomatous } \\
\text { polyp burden }\end{array}$ & 50 to thousands & $<50$ & $<100$ & $\begin{array}{l}\text { A significant proportion } \\
\text { of syndromic juvenile } \\
\text { polyps will harbor areas } \\
\text { of adenomatous } \\
\text { transformation. }{ }^{17}\end{array}$ & \\
\hline $\begin{array}{l}\text { Hamartomatous } \\
\text { polyps }\end{array}$ & None & None & None & $\begin{array}{l}\text { Variable, mainly } \\
\text { colorectal** }^{*}\end{array}$ & $\begin{array}{l}\text { Variable colorectal } \\
\text { and gastric; typically } \\
\text { small intestinal } \\
\text { involvement }\end{array}$ \\
\hline $\begin{array}{l}\text { Age of polyp } \\
\text { onset }\end{array}$ & In the 2 nd decade of life & $\begin{array}{l}\text { Variable, often 3rd } \\
\text { decade }\end{array}$ & $\begin{array}{l}\text { Variable, usually } \\
\text { after } 50\end{array}$ & $\begin{array}{l}\text { Variable, usually 1st, } \\
\text { 2nd decades of life }\end{array}$ & $\begin{array}{l}\text { Variable, usually 1st, } \\
\text { 2nd decades of life }\end{array}$ \\
\hline $\begin{array}{l}\text { Average age of } \\
\text { cancer onset }\end{array}$ & $\begin{array}{l}\text { Hepatoblastoma in 1st } \\
\text { decade; thyroid in 1st } \\
\text { and } 2 \text { nd; brain in latter } \\
\text { half of the 1st decade; } \\
\text { colon in the } 3 \text { rd decade. }\end{array}$ & 55 & $\begin{array}{l}\text { Variable } \\
\text { (unknown) }\end{array}$ & $\begin{array}{l}\text { Variable (> } 30 \% \text { by } 60 \\
\text { years of age) }\end{array}$ & Variable \\
\hline $\begin{array}{l}\text { Extracolonic } \\
\text { cancers }\end{array}$ & $\begin{array}{l}\text { Small bowel, gastric, } \\
\text { periampullary, } \\
\text { duodenal, pancreas, } \\
\text { brain tumours (Turcot } \\
\text { syndrome), } \\
\text { hepatoblastoma }\end{array}$ & $\begin{array}{l}\text { Small bowel, gastric, } \\
\text { periampullary, } \\
\text { duodenal, pancreas, } \\
\text { brain tumours } \\
\text { (Turcot syndrome), } \\
\text { hepatoblastoma }\end{array}$ & $\begin{array}{l}\text { Sebaceous gland } \\
\text { tumours (skin), } \\
\text { breast }\end{array}$ & Gastric, small bowel & $\begin{array}{l}\text { Testicular (sertoli } \\
\text { cell), ovarian } \\
\text { (granulosa cell) } \\
\text { pancreatic }\end{array}$ \\
\hline $\begin{array}{l}\text { Germline } \\
\text { mutations }\end{array}$ & $\begin{array}{l}A P C \text { (mutation unknown } \\
\text { in } 20 \% \text { of patients) }\end{array}$ & $\begin{array}{l}A P C \\
\text { (mutation unknown } \\
\text { in } 20 \% \text { of patients) }\end{array}$ & $M Y H$ & $\begin{array}{l}\text { BMPR1A, SMAD } \\
\text { (mutation unknown in } \\
40 \%-60 \% \text { of patients) }\end{array}$ & $\begin{array}{l}\text { PTEN, STK } 11 \\
\text { (mutation unknown } \\
\text { in } 50 \% \text { of patients) }\end{array}$ \\
\hline
\end{tabular}

*Gastric hamartomatous polyps are more common in patients harboring a SMAD4 gene mutation. 
Table 2: Screening and surveillance recommendations by age for patients with hereditary polyposis syndromes ${ }^{17-19}$

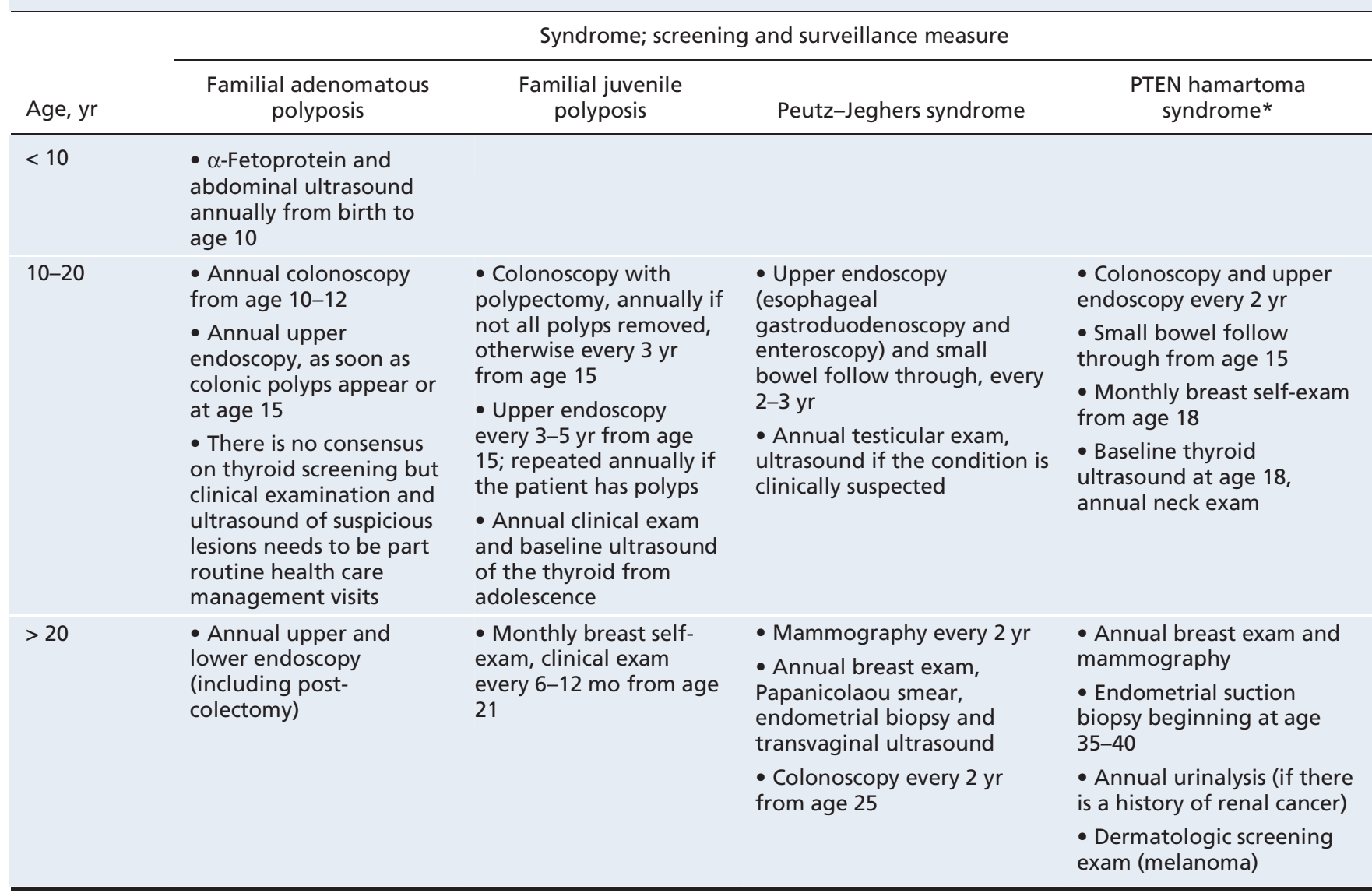

*Also known as Cowden syndrome and Bannayan-Riley-Ruvalcaba syndrome.

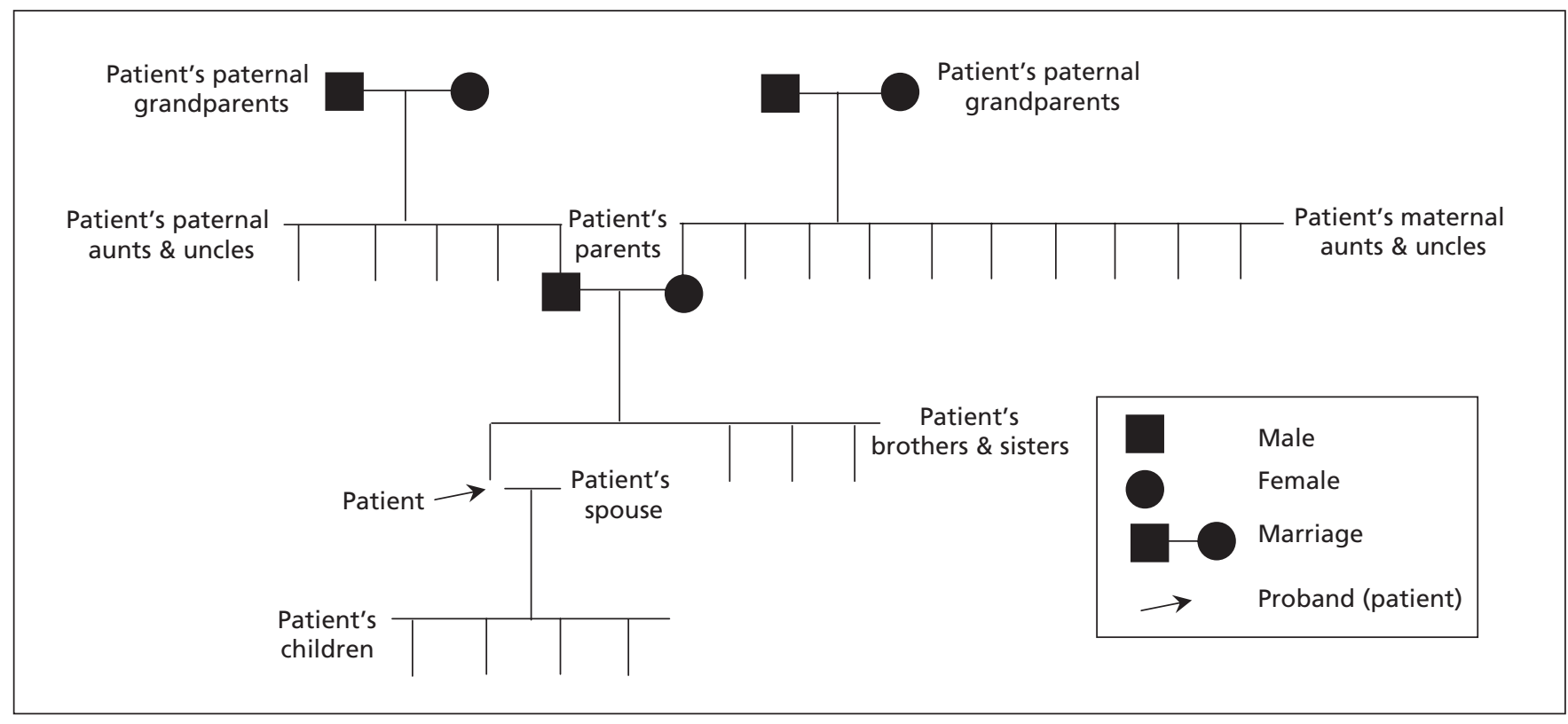

Figure 2: Patient's modified nuclear pedigree, which depicts the minimal amount of information required for a comprehensive family history of colon cancer. This involves detailed description of the patient (arrow), her siblings, children, parents, maternal and paternal aunts, uncles and grandparents. Reproduced with permission Karger. ${ }^{21}$ 
should receive mutation-specific testing. Considerations include whether cancer-causing mutation is known to segregate in the family; whether the mutation has been identified in a candidate family member; whether the individual patient is at high risk of cancer because of his or her position in the pedigree or has a syndrome-associated cancer; and whether the patient has a cancer syndrome stigmata (phenotype) (e.g., multiple polyposis in familial adenomatous polyposis).

Patients should be encouraged to take responsibility for informing their relatives who may be at risk about the hereditary disorder and the opportunities available to them. Educational materials should be made available. A 14-page booklet for patients, entitled Living with Hereditary Colorectal Cancer, has been developed by our team at Creighton (copies of the booklet and information about reprinting are available from the corresponding author). In addition, there are several websites with useful information. The American Society for Clinical Oncology sponsors Cancer.net, which has information for patients with Lynch syndrome (www.cancer.net/patient /Cancer+Types/Hereditary+Non-Polyposis+Colorectal+Cancer). The Colorectal Cancer Coalition's website also has information for patients (http://fightcolorectalcancer.org/awareness /patients/prevention/risk). When possible, family members should be given the opportunity to participate in a family information service, ${ }^{29}$ which can be effective in enhancing cancer control through its informal group educational and therapeutic benefits.

\section{Surveillance and management}

Once Lynch syndrome has been diagnosed, medical management involves a highly targeted screening and management program, which is based on the syndrome's natural history (Box 1). Table 3 shows the level of evidence for the most common screening and management modalities. ${ }^{30}$ Lindor and colleagues $^{30}$ note that evidence from many studies is insufficient to recommend for or against most of these practices. It is therefore necessary to base recommendations, at least in part, on the characteristics and natural history of the disorder.

Colonoscopic screening has been shown to significantly improve survival among carriers of a mutation associated with Lynch syndrome. ${ }^{31,32}$ Lindor and colleagues ${ }^{30}$ reported that the available evidence strongly supports colonoscopic surveillance for patients with Lynch syndrome, and they recommended this procedure every 1-2 years, starting between the ages of 20 and 25. Those with a mutation in MSH6 should start screening at age 30. Features of Lynch syndromeassociated colorectal cancer that are addressed by these recommendations include early age of cancer onset, accelerated carcinogenesis of adenomas into carcinomas, and predilection to cancer of the proximal colon (about $70 \%$ of Lynch syndrome-related colorectal cancers occur in the right colon, which is not accessed through sigmoidoscopy). ${ }^{4,7}$ There is continuing research into improvements in colonoscopic detection of polyps and adenomas, such as chromoscopic colonoscopy ${ }^{33,34}$ and the use of narrow band imaging. ${ }^{35}$

Lindor and colleagues ${ }^{30}$ recommend subtotal colectomy for patients with Lynch syndrome who have colorectal cancer,

\section{Box 1: Features of Lynch syndrome $e^{4,26}$}

- Autosomal dominant inheritance pattern

- Earlier average age of onset of colorectal cancer than in the general population (45 years in Lynch syndrome v. 63 years in the general population)

- Proximal (right-sided) colonic cancer predilection (70\%-85\% of colorectal cancers in Lynch syndrome are proximal to the splenic flexure)

- Accelerated carcinogenesis (tiny adenomas can develop carcinomas within 2-3 years in Lynch syndrome v. 8-10 years in the general population)

- High risk of additional colorectal cancers (25\%-30\% of patients who have surgery for a Lynch syndromeassociated colorectal cancer have a second primary colorectal cancer within 10 years of surgical resection if they received a less than subtotal colectomy)

- Increased risk of malignant disease at certain extracolonic sites: ${ }^{20}$

- endometrium (40\%-60\% lifetime risk for female mutation carriers)

- ovary $(12 \%-15 \%$ lifetime risk for female mutation carriers)

- stomach (higher risk in people of Asian descent)

- small bowel

- hepatobiliary tract

- pancreas

- upper uroepithelial tract (transitional cell carcinoma of the ureter and renal pelvis)

- brain (in the Turcot syndrome variant of Lynch syndrome)

- Sebaceous adenomas, sebaceous carcinomas and multiple keratoacanthomas in Muir-Torre syndrome (variant of Lynch syndrome)

- Pathology of colorectal cancer is more often poorly differentiated, with an excess of mucoid and signet-cell features, a Crohn-like reaction and an excess of infiltrating lymphocytes within the tumour

- Increased survival from colorectal cancer

- Germline mutation in a mismatch repair gene (most commonly $\mathrm{MLH1}, \mathrm{MSH} 2$ or $\mathrm{MSH} 6$ ) that segregates in the patient's family (i.e., members who carry the mutation show a much higher rate of syndrome-related cancers than those who do not carry the mutation.)

and they also recommend urinalysis with cytology beginning between age 25 and 35 .

Following colorectal cancer, the second most frequent cancer in Lynch syndrome is endometrial carcinoma (occurs in $40 \%-60 \%$ of women with the mutation), followed by carcinoma of the ovary (occurs in about $12 \%-15 \%$ of women with the mutation).$^{20}$ Based on their study of the evidence, Lindor and colleagues ${ }^{30}$ recommend endometrial sampling and transvaginal ultrasonography of the uterus beginning between age 30 and 35. They also recommend transvaginal ultrasonograpy of the ovaries beginning at the same age. We agree with these recommendations, with the caveat that the patient must be fully apprised of the screening limitations for early detection of ovarian cancer, as well as the lack of evidence of a reduction in mortality through endometrial and ovarian screening. 
Table 3: Recommended management for at-risk members of families with Lynch syndrome (Reproduced with permission from the American Medical Association. ${ }^{30}$ )

\begin{tabular}{|c|c|c|c|}
\hline Type of intervention & Recommendation & $\begin{array}{l}\text { Quality of evidence } \\
\text { regarding intervention }\end{array}$ & Strength of recommendation* \\
\hline \multirow{2}{*}{$\begin{array}{l}\text { Screening } \\
\text { colonoscopy }\end{array}$} & \multirow{2}{*}{$\begin{array}{l}\text { Every } 1-2 \text { yr beginning at age } \\
20-25 \text { yr (age } 30 \text { yr in MSH6 families), } \\
\text { or } 10 \text { yr younger than the youngest } \\
\text { age at diagnosis in the family, } \\
\text { whichever comes first }\end{array}$} & \multirow[b]{2}{*}{$\begin{array}{l}\text { Evidence includes } \\
\text { consistent results from } \\
\text { well-designed, well- } \\
\text { conducted studies in } \\
\text { representative } \\
\text { populations that directly } \\
\text { assess effects on health } \\
\text { outcomest }\end{array}$} & Strongly recommended \\
\hline & & & $\begin{array}{l}\text { There is good evidence that the } \\
\text { guideline improves important health } \\
\text { outcomes and concludes that benefits } \\
\text { substantially outweigh harms }\end{array}$ \\
\hline \multirow[t]{2}{*}{ Endometrial sampling } & \multirow[t]{2}{*}{ Every year beginning at age $30-35 \mathrm{yr}$} & \multirow{2}{*}{$\begin{array}{l}\text { Evidence is insufficient } \\
\text { to assess the effects on } \\
\text { health outcomes } ¥\end{array}$} & $\begin{array}{l}\text { Insufficient evidence to recommend for } \\
\text { or against }\end{array}$ \\
\hline & & & $\begin{array}{l}\text { Evidence is lacking, of poor quality, or } \\
\text { conflicting, and the balance of benefits } \\
\text { and harms cannot be determined }\end{array}$ \\
\hline \multirow{2}{*}{$\begin{array}{l}\text { Transvaginal } \\
\text { ultrasound for } \\
\text { endometrial and } \\
\text { ovarian cancer }\end{array}$} & \multirow[t]{2}{*}{ Every year beginning at age $30-35 \mathrm{yr}$} & \multirow{2}{*}{$\begin{array}{l}\text { Evidence is insufficient } \\
\text { to assess the effects on } \\
\text { health outcomes } ¥\end{array}$} & $\begin{array}{l}\text { Insufficient evidence to recommend for } \\
\text { or against }\end{array}$ \\
\hline & & & $\begin{array}{l}\text { Evidence is lacking, of poor quality, or } \\
\text { conflicting, and the balance of benefits } \\
\text { and harms cannot be determined }\end{array}$ \\
\hline \multirow[t]{2}{*}{$\begin{array}{l}\text { Urinalysis with } \\
\text { cytology }\end{array}$} & \multirow[t]{2}{*}{$\begin{array}{l}\text { Every } 1-2 \text { yr beginning at age } \\
25-35 \text { yr }\end{array}$} & \multirow{2}{*}{$\begin{array}{l}\text { Evidence is insufficient } \\
\text { to assess the effects on } \\
\text { health outcomes } ¥\end{array}$} & $\begin{array}{l}\text { Insufficient evidence to recommend for } \\
\text { or against }\end{array}$ \\
\hline & & & $\begin{array}{l}\text { Evidence is lacking, of poor quality, or } \\
\text { conflicting, and the balance of benefits } \\
\text { and harms cannot be determined }\end{array}$ \\
\hline \multirow{2}{*}{$\begin{array}{l}\text { History and } \\
\text { examination with } \\
\text { detailed review of } \\
\text { systems, education, } \\
\text { and counselling } \\
\text { regarding Lynch } \\
\text { syndrome }\end{array}$} & \multirow[t]{2}{*}{ Every year beginning at age $21 \mathrm{yr}$} & \multirow{2}{*}{$\begin{array}{l}\text { Evidence is insufficient } \\
\text { to assess the effects on } \\
\text { health outcomes } ¥\end{array}$} & $\begin{array}{l}\text { Insufficient evidence to recommend for } \\
\text { or against }\end{array}$ \\
\hline & & & $\begin{array}{l}\text { Evidence is lacking, of poor quality, or } \\
\text { conflicting, and the balance of benefits } \\
\text { and harms cannot be determined }\end{array}$ \\
\hline \multirow{3}{*}{$\begin{array}{l}\text { Prophylactic surgery } \\
\text { Colorectal resection } \\
\text { (segmental v. subtotal } \\
\text { colectomy v. complete } \\
\text { proctocolectomy) }\end{array}$} & \multirow{2}{*}{$\begin{array}{l}\text { For at-risk persons without colorectal } \\
\text { neoplasia: generally not } \\
\text { recommended, discuss as alternative } \\
\text { to regular colonoscopy, with } \\
\text { preferences of well-informed patient } \\
\text { actively elicited }\end{array}$} & \multirow{3}{*}{$\begin{array}{l}\text { Evidence is insufficient } \\
\text { to assess the effects on } \\
\text { health outcomes }\end{array}$} & $\begin{array}{l}\text { Insufficient evidence to recommend for } \\
\text { or against }\end{array}$ \\
\hline & & & $\begin{array}{l}\text { Evidence is lacking, of poor quality, or } \\
\text { conflicting, and the balance of benefits } \\
\text { and harms cannot be determined }\end{array}$ \\
\hline & $\begin{array}{l}\text { For persons with a diagnosed cancer } \\
\text { or polyp not resectable by } \\
\text { colonoscopy, } § \text { subtotal colectomy } \\
\text { favoured with preferences of well- } \\
\text { informed patient actively elicited }\end{array}$ & & \\
\hline \multirow{2}{*}{$\begin{array}{l}\text { Hysterectomy or } \\
\text { oophorectomy }\end{array}$} & \multirow{2}{*}{$\begin{array}{l}\text { Discuss as option after childbearing } \\
\text { completed }\end{array}$} & \multirow[t]{2}{*}{ Good-fairף } & No recommendation for or against \\
\hline & & & $\begin{array}{l}\text { There is at least fair evidence that the } \\
\text { guideline can improve health outcomes } \\
\text { but the balance of benefits and harms } \\
\text { is too close to justify a general } \\
\text { recommendation }\end{array}$ \\
\hline
\end{tabular}

*Adapted from the US Preventive Services Task Force's 2-tier system to assess the quality of evidence and to assign strength of recommendations in support of each guideline.

tWhile the quality of evidence supporting colon examination is good, the optimal frequency and initiation age have not been adequately studied.

$\ddagger$ Because of limited number or power of studies, important flaws in their design or conduct, gaps in the chain of evidence, or lack of information on important health outcomes.

§Resection of a colon neoplasm is therapeutic, not prophylactic. At issue is the extent of resection - if greater than otherwise required by usual surgical considerations, then it carries an element of prophylaxis. Because all persons in this group will be undergoing surgery, there is opportunity to consider prophylactic removal of much or all of the colon. For women, the discussion should include option of having a hysterectomy or oophorectomy at the same time. qDefined as evidence that includes consistent results from well-designed, well-conducted studies in representative populations that directly assess effects on health outcomes but the strength of the evidence is limited by the number, quality, or consistency of the individual studies, generalizability to routine practice, or indirect nature of the evidence on health outcomes. 
The efficacy of prophylactic hysterectomy and bilateral salpingo-oophorectomy in women who have a Lynch syndrome-related germline mutation is supported by evidence-based findings, and this should be offered as an option for cancer prevention after a woman's family is completed. ${ }^{36}$

Screening for more uncommon cancers integral to Lynch syndrome varies depending on specific family history; therefore, this is best addressed by a genetic counselor.

Hereditary colorectal cancer syndromes provide a wealth of opportunities for highly targeted clinical management and prevention. The key to prevention is early diagnosis through a comprehensive family history, followed by germline mutation testing if appropriate, and targeted surveillance and management for patients with mutations.

An extremely useful set of guidelines is that of the National Comprehensive Cancer Network, ${ }^{37}$ which can be ordered in print or used as an interactive tool on the Network's website. The network offers colorectal cancer screening guidelines for patients at average or increased risk, including algorithms to assist in recognizing the likely presence of various hereditary colorectal cancer syndromes, deciding if a referral for genetic testing is warranted, and providing management after diagnosis. An advantage of the interactive tool on the website is that physicians can find detailed information and recommendations for the set of variables presented by a specific patient without needing to wade through similar material for the myriad other possible situations.

The American Gastroenterological Association also publishes guidelines that are periodically updated on colorectal cancer screening and surveillance for patients at average and high risk. ${ }^{38}$ These provide an excellent background and overview, but, because of their nature, they are not as comprehensive as those by the National Comprehensive Cancer Network.

\section{Lynch syndrome as a model for clinical cancer control}

The characteristic clinical features of Lynch syndrome are shown in Box 1. This information is often extremely helpful in establishing a diagnosis and determining who should be tested. For a more detailed discussion, see the articles by Lynch and de la Chapelle., ${ }^{411}$

The original Amsterdam criteria ${ }^{39}$ were designed to provide uniformity in collaborative research studies and looked at only personal and familial histories of colorectal cancer. When these criteria were determined to be too stringent, the Amsterdam Criteria $\mathrm{II}^{40}$ were developed. These criteria considered the extracolonic cancers in the Lynch syndrome tumour spectrum, thereby making the diagnosis more specific. Both sets of Amsterdam criteria were used before the development of molecular-based diagnostic tools such as microsatellite instability and immunohistochemistry testing. More recently, the Bethesda Guidelines (Box 2) ${ }^{41,42}$ were developed, which make use of new molecular and pathologic knowledge and have proven to be of even greater use in determining who should receive genetic testing. ${ }^{43}$ Microsatellite instability testing is indicated when any one of the guideline criteria is met. ${ }^{44}$
Box 2: Bethesda guidelines for testing colorectal tumours for microsatellite instability ${ }^{41}$

The following groups of patients should receive testing for microsatellite instability:

- Patients aged less than 50 years with a diagnosis of colorectal cancer.

- Patients with synchronous or metachronous colorectal or other syndrome-associated tumours, * regardless of age.

- Patients aged less than 60 years with colorectal cancer with microsatellite instability-hight histology. $\dagger$

- Patients with at least 1 first-degree relative with a diagnosis of colorectal cancer or a syndrome-associated tumour* under age 50 years.

- Colorectal cancer or syndrome-associated tumour* diagnosed at any age in 2 first- or second-degree relatives.

*Includes colorectal, endometrial, stomach, ovarian, pancreas, ureter or renal pelvis, biliary tract and brain (usually glioblastoma as seen in Turcot syndrome) tumours, sebaceous gland adenomas and keratoacanthomas in Muir-Torre syndrome and carcinoma of the small bowel. tPresence of tumour infiltrating lymphocytes, Crohn disease-like lymphocytic reaction, mucinous or signet-ring differentiation, or medullary growth pattern.

Although the original Amsterdam criteria are no longer used to diagnose Lynch syndrome, they have more recently proved useful in the identification of another subset of possibly hereditary colorectal cancers. Lindor and colleagues, ${ }^{9}$ as well as some other researchers, have described families that fulfill the original Amsterdam criteria but lack the mismatch repair mutation findings necessary for diagnosis of Lynch syndrome; such families have what is referred to as "familial colorectal cancer type X."

\section{Summary}

Increased knowledge of genetics and molecular pathophysiologic pathways holds the promise for the development and timing of screening measures, such as colonoscopy, which may facilitate detection of presymptomatic cancer and potentially a reduction of mortality. Insight into the molecular genetic mechanisms of hereditary cancer syndromes may improve targeted cancer control measures and pharmacologic therapy. Thus, it may one day become possible to select therapy based on genomic or proteomic profiles for targeted molecular-based pharmacologic therapy. Physicians must attain a better grasp of hereditary cancer syndromes and, when more expertise is needed, make appropriate referrals to experienced medical geneticists or a centre with expertise in hereditary cancer. Lives can be saved through cancer prevention using genetic knowledge.

This article has been peer reviewed.

Competing interests: None declared.

Contributors: Henry Lynch, Jane Lynch and Thomas Attard each made substantial contributions to the analysis and interpretation of data, drafting the article and revising it critically for important intellectual content, and gave final approval of the version to be published. In addition, Henry Lynch and Thomas Attard made substantial contributions to conception and design and acquisition of data. 
Funding: This paper was supported by revenue from Nebraska cigarette taxes awarded to Creighton University by the Nebraska Department of Health and Human Services. Its contents are solely the responsibility of the authors and do not necessarily represent the official views of the State of Nebraska or the Nebraska Department of Health and Human Services.

Support was also given by the National Institutes of Health through grant \#1U01 CA 86389.

Henry Lynch's work is partially funded through the Charles F. and Mary C. Heider Chair in Cancer Research, which he holds at Creighton University.

\section{REFERENCES}

1. Lynch HT, Riley BD, Weismann S, et al. Hereditary nonpolyposis colorectal carcinoma (HNPCC) and HNPCC-like families: Problems in diagnosis, surveillance and management. Cancer 2004;10053-64.

2. Hampel H, Frankel WL, Martin E, et al. Feasibility of screening for Lynch syndrome among patients with colorectal cancer. J Clin Oncol 2008;26:5783-8.

3. Canadian Cancer Society. Canadian Cancer Statistics 2008. Toronto (ON): The Society; 2008. Available: www.cancer.ca/canada-wide/about\%20cancer/cancer $\% 20$ statistics/canadian\%20cancer\%20statistics.aspx?sc_lang=en (accessed 2009 June 22).

4. Lynch HT, de la Chapelle A. Genomic medicine: hereditary colorectal cancer. $N$ Engl J Med 2003;348:919-32.

5. Lynch HT, Shaw MW, Magnuson CW, et al. Hereditary factors in cancer: study of two large Midwestern kindreds. Arch Intern Med 1966;117:206-12.

6. Boland CR. Evolution of the nomenclature for the hereditary colorectal cancer syndromes. Fam Cancer 2005;4:211-8.

7. Vasen HFA, Boland CR. Progress in genetic testing, classification, and identification of Lynch syndrome. JAMA 2005;293:2028-30.

8. Online Mendelian Inheritance in Man. Baltimore (MD): McKusick-Nathans Institute for Medical Genetics, Johns Hopkins University; 2008. Available: www.ncbi.nlm.nih.gov/omim/ (accessed 2009 June 22).

9. Lindor NM, Rabe K, Petersen GM, et al. Lower cancer incidence in Amsterdam-I criteria families without mismatch repair deficiency: Familial colorectal cancer type X. JAMA 2005;293:1979-85.

10. Frazier ML, Xi L, Zong J, et al. Association of the CpG island methylator phenotype with family history of cancer in patients with colorectal cancer. Cancer Res 2003;63:4805-8

11. Lynch HT, de la Chapelle A. Genetic susceptibility to non-polyposis colorectal cancer. J Med Genet 1999;36:801-18.

12. Nielsen M, Franken PF, Reinards TH, et al. Multiplicity in polyp count and extracolonic manifestations in 40 Dutch patients with MYH associated polyposis coli (MAP). J Med Genet 2005;42:e54.

13. Barnetson RA, Devlin L, Miller J, et al. Germline mutation prevalence in the base excision repair gene, MYH, in patients with endometrial cancer. Clin Genet 2007;72:551-5.

14. Ponti G, Ponz de Leon M, Maffei S, et al. Attenuated familial adenomatous polyposis and Muir-Torre syndrome linked to compound biallelic constitutional MYH gene mutations. Clin Genet 2005;68:442-7.

15. Ajith Kumar VK, Gold JA, Mallon E, et al. Sebaceous adenomas in an MYH associated polyposis patient of Indian (Gujarati) origin. Fam Cancer 2008;7:187-9. Epub 2007 Sep 15.

16. Olschwang $\mathrm{S}$, Blanché $\mathrm{H}$, de Moncuit $\mathrm{C}$, et al. Similar colorectal cancer risk in patients with monoallelic and biallelic mutations in the MYH gene identified in a population with adenomatous polyposis. Genet Test 2007;11:315-20.

17. Wu TT, Rezai B, Rashid A, et al. Genetic alterations and epithelial dysplasia in juvenile polyposis syndrome and sporadic juvenile polyps. Am J Pathol 1997;150:939-47.

18. Howe JR, Mitros FA, Summers RW. The risk of gastrointestinal carcinoma in familial juvenile polyposis. Ann Surg Oncol 1998;5:751-6.

19. Giardiello FM, Welsh SB, Hamilton SR, et al. Increased risk of cancer in the Peutz-Jeghers syndrome. N Engl J Med 1987;316:1511-4.

20. Watson P, Vasen HFA, Mecklin J-P, et al. The risk of extra-colonic, extraendometrial cancer in the Lynch syndrome. Int J Cancer 2008;123:444-9.

21. Lynch HT, Rozen P, Schuelke GS, et al. Hereditary colorectal cancer review: colonic polyposis and nonpolyposis colonic cancer (Lynch syndrome I and II). Surv Dig Dis 1984;2:244-60.

22. Murff HJ, Byrne D, Syngal S. Cancer risk assessment: Quality and impact of the family history interview. Am J Prev Med 2004;27:239-45.

23. Guttmacher AE, Collins FS, Carmona RH. The family history - more important than ever. N Engl J Med 2004;351:2333-6.

24. Murff HJ, Spigel DR, Syngal S. Does this patient have a family history of cancer? An evidence-based analysis of the accuracy of family cancer history. JAMA 2004;292:1480-9.

25. Murff HJ, Greevy RA, Syngal S. The comprehensiveness of family cancer history assessments in primary care. Community Genet 2007;10:174-80.

26. Lynch HT, Boland CR, Gong G, et al. Phenotypic and genotypic heterogeneity in the Lynch syndrome: diagnostic, surveillance and management implications. Eur J Hum Genet 2006;14:390-402.

27. Lynch HT, Boland CR, Rodriguez-Bigas MA, et al. Who should be sent for genetic testing in hereditary colorectal cancer syndromes? J Clin Oncol 2007;25: 3534-42.

28. Taylor KM, Kelner MJ. The emerging role of the physician in genetic counselling and testing for heritable breast, ovarian and colon cancer. CMAJ 1996;154:1155-8.

29. Lynch HT. Family information service and hereditary cancer. Cancer 2001;91:625-8.

30. Lindor NM, Petersen GM, Hadley DW, et al. Recommendations for the care of individuals with an inherited predisposition to Lynch syndrome: a systematic review. JAMA 2006;296:1507-17.

31. Järvinen HJ, Aarnio M, Mustonen H, et al. Controlled 15-year trial on screening for colorectal cancer in families with hereditary nonpolyposis colorectal cancer. Gastroenterology 2000;118:829-34.

32. Dove-Edwin I, Sasieni P, Adams J, et al. Prevention of colorectal cancer by colonoscopic surveillance in individuals with a family history of colorectal cancer: 16 year, prospective, follow-up study. BMJ 2005;331:1047.

33. Hurlstone DP, Karajeh M, Cross SS, et al. The role of high-magnificationchromoscopic colonoscopy in hereditary nonpolyposis colorectal cancer screening: A prospective "back-to-back" endoscopic study. Am J Gastroenterol 2005; 100:2167-73.

34. Lecomte T, Cellier C, Meatchi T, et al. Chromoendoscopic colonoscopy for detecting preneoplastic lesions in hereditary nonpolyposis colorectal cancer syndrome. Clin Gastroenterol Hepatol 2005;3:897-902.

35. East JE, Suzuki N, Stavrinidis M, et al. Narrow band imaging for colonoscopic surveillance in hereditary non-polyposis colorectal cancer. Gut 2008;57:65-70.

36. Schmeler KM, Lynch HT, Chen L-M, et al. Prophylactic surgery to reduce the risk of gynecologic cancers in the Lynch syndrome. N Engl J Med 2006;354:261-9.

37. NCCN Clinical Practice Guidelines in Oncology. Fort Washington (PA): National Comprehensive Cancer Network; 2009. Available: www.nccn.org/professionals /physician_gls/PDF/colon.pdf (accessed 2009 June 30).

38. Winawer S, Fletcher R, Rex D, et al. Colorectal cancer screening and surveillance: clinical guidelines and rationale-update based on new evidence. Gastroenterology 2003;124:544-60.

39. Vasen HFA, Mecklin J-P, Meera Khan P, et al. The International Collaborative Group on Hereditary Nonpolyposis Colorectal Cancer (ICG-HNPCC). Dis Colon Rectum 1991:34:424-5.

40. Vasen HFA, Watson P, Mecklin J-P, et al. ICG-HNPCC. New clinical criteria for hereditary nonpolyposis colorectal cancer (HNPCC, Lynch syndrome) proposed by the International Collaborative Group on HNPCC. Gastroenterology 1999;116:1453-6.

41. Umar A, Boland CR, Terdiman JP, et al. Revised Bethesda guidelines for hereditary nonpolyposis colorectal cancer (Lynch syndrome) and microsatellite instability. J Natl Cancer Inst 2004:96:261-8.

42. Laghi L, Bianchi P, Roncalli M, et al. Revised Bethesda guidelines for hereditary nonpolyposis colorectal cancer (Lynch syndrome) and microsatellite instability [letter]. J Natl Cancer Inst 2004;96:1402-3.

43. Piñol V, Castells A, Andreu M, et al. Accuracy of revised Bethesda guidelines, microsatellite instability, and immunohistochemistry for the identification of patients with hereditary nonpolyposis colorectal cancer. JAMA 2005;293:1986-94.

44. Abdel-Rahman WM, Peltomäki P. Lynch syndrome and related familial colorectal cancers. Crit Rev Oncog 2008;14:1-21.

Correspondence to: Dr. Henry T. Lynch, Department of

Preventive Medicine and Public Health, Creighton University School of Medicine, 2500 California Plaza, Omaha NE 68178, USA; fax 402 280-1734; htlynch@creighton.edu 